Gelanggang Olahraga: Jurnal Pendidikan Jasmani dan Olahraga

Volume 1, Nomor 2, Januari-Juni 2018

e-ISSN : 2597-6567

p-ISSN : 2614-607X

DOI : https://doi.org/10.31539/jpjo.v1i2.130

\title{
PENGARUH METODE LATIHAN INTERVAL INTENSIF DAN INTER VAL EKSTENSIF TERHADAP PENINGKATAN VO2 MAX
}

\author{
Muhammad Suhdy \\ STKIP PGRI Lubuklinggau \\ msuhdy@stkippgri-lubuklinggau.ac.id
}

\begin{abstract}
ABSTRAK
Tujuan penelitian untuk membuktikan pengaruh metode latihan interval intensif dan ekstensif terhadap peningkatan VO2 Max. Jenis penelitian ini adalah Eksperimen semu dengan menggunakan rancangan penelitian Randomized Pretest-Posttest Design Group. Metode penelitian mengunakan Latihan Interval intensif dan Latihan Interval ekstensif. Hasil penelitian ini didapat korelasi kedua kelompok tes sebesar 0.491 dengan signifikansi 0.150 , paired sample test, diperoleh mean differences sebesar 3.530. $\mathrm{T}_{\mathrm{hit}}=3.187>\mathrm{t}_{\mathrm{tab}} 2.262$, dengan $d f=9$, $P=0.011$. Hal ini membuktikan adanya perbedaan secara nyata pada VO2 Max kedua kelompok tes latihan interval intensif. Selanjutnya paired sample test, diperoleh mean differences sebesar 6.410. $\mathrm{T}_{\text {hit }}=5.702>\mathrm{t}_{\mathrm{tab}} 2.262$, dengan $d f=9$, $P=0.000$. Hal ini membuktikan adanya perbedaan secara nyata pada VO2 Max kedua kelompok tes metode latihan ekstensif dan paired sample test, diperoleh mean differences sebesar 8.640. $\mathrm{T}_{\text {hit }}=10.640>\mathrm{t}_{\mathrm{tab}} 2.262$, dengan $d f=9, P$ $=0.000$. Hal ini membuktikan adanya perbedaan secara nyata pada VO2 Max kedua kelompok tes metode latihan intensif dan ekstensif. Dimana metode latihan interval ekstensif lebih baik dari metode latihan intensif.
\end{abstract}

Kata Kunci: Metode Latihan Intenval Intensif, Ekstensif, Vo2max

\begin{abstract}
The objective of the study was to demonstrate the effect of intensive and extensive interval training methods on the improvement of VO2Max. This type of research is a quasi experiment using Randomized Pretest-Posttest Design Group research design. The research method used Intensive Interval Training and extensive Interval Training. The results of this study obtained the correlation of both test groups of 0.491 with significance of 0.150 , paired sample test, obtained by the mean differences of 3.530. Thit $=3.187>t$ tab 2.262, with $d f=9, P=0.011$. This proves a significant difference in the second group VO2Max intensive interval training test. Next paired sample test, obtained the mean differences of 6.410. Thit $=5.702>t$ tab 2.262, with $d f=9, P=0.000$. This proves that there is a significant difference in the VO2Max of both groups of tests of extensive training methods and paired sample test, obtained by mean differences of 8,640. Thit $=10.640>$ ttab 2.262, with $d f=9, P=0.000$. This proves a significant difference in both groups of VO2Max intensive and extensive exercise test methods. Where extensive interval training methods are better than intensivetraining methods
\end{abstract}

Keywords: Intensive, Extensive, Extensive, Vo2max Intenval Exercise Method 


\section{PENDAHULUAN}

Olahraga merupakan kegiatan yang di butuhkan oleh setiap orang untuk mendapatkan kesegaran jasmani, kesegaran pemikiran, dan berpartisipasi dalam pekerjaan, sehingga dapat meningkatkan produktifitas kerja. di sisi lain olahraga juga dapat dijadikan ajang kompetisi untuk berpacu dalam pencapaian sebuah prestasi, sebagai wujud untuk mempertahankan prestasi baik secara individu, kelompok maupun negara dan bangsa. Dewasa ini pemerintah tampak serius dalam membangun olahraga prestasi dengan berbagai upaya, hal ini seperti yang dinyatakan dalam Undang Undang Republik Indonesia Nomor 3 Tahun 2005 tentang Sistem Keolahragaan Nasional, yakni "pembinaan dan pengembangan olahraga prestasi dilaksanakan dan diarahkan untuk mencapai prestasi olahraga pada tingkat daerah, nasional dan internasional “

Dengan demikian untuk mencapai prestasi yang baik sangat diharapkan dukungan pemerintah pusat, maupun daerah serta masyarakat. Sekarang dukungan pemerintah sangat tinggi untuk membangun olahraga prestasi sepakbola sebagai salah satu cabang olahraga yang sangat digemari oleh masyarakat diharapkan ikut serta dalam mewujudkan tujuan tersebut. Olahraga sepakbola adalah salah satu cabang olahraga yang sangat popular di dunia. Sepakbola telah banyak mengalami perubahan dan perkembangan dari bentuk sederhana dan primitif sampai menjadi sepakbola modren yang sangat di gemari dan disenangi banyak orang, baik anakanak, dewasa, tua dan bahkan wanita. Hal ini dapat kita lihat begitu banyaknya orang yang menyenangi olahraga ini baik sebagai penonton maupun langsung sebagai pemain, mulai dari perkotaan sampai pedesaan.

Dilihat dari Tim Nasional Indonesia pada masa sekarang ini sudah mulai cukup membanggakan kembali walaupun tidak dapat meraih prestasi yang diinginkan. Terlihat dari semangat dan stamina yang mereka miliki dalam bermain pada Piala AFF. Sedangkan kita lihat dari segi pemain muda Indonesia yang tergabung dalam Liga Pendidikan Indonesia (LPI) masih banyak yang harus di perhatikan dan di perbaiki kembali. Seperti lemahnya kondisi fisik, daya tahan baik umum maupun khusus dan kemampuan VO2 Max mereka begitu juga stamina. Untuk itu, dalam pencapaian prestasi yang maksimal dalam sepakbola ada empat faktor yang perlu mendapat perhatian yaitu : 1) kondisi fisik, 2) teknik, 3) taktik dan strategi, 4) mental. Tanpa kondisi fisik yang baik tidak mungkin seorang mampu menguasai teknik dengan baik. Selain itu teknik juga membutuhkan mental yang baik karena mental mempengaruhi teknik baik individual maupun kelompok. latihan olahraga merupakan proses penyempurnaan atlet secara dasar untuk mencapai mutu prestasi maksimal dengan di berikan beban fisik, teknik, taktik dan mental secara teratur, terarah, meningkat, bertahap dan berulang-ulang" (Bompa, 2005)

Kutipan di atas dapat dijelaskan, bahwa untuk mencapai mutu dan prestasi maksimal tentunya harus melalui sesuatu proses pembinaan mulai sejak dini, agar prestasi yang diharapkan dapat tercapai dengan baik sehingga meningkatkan kualitas para atlit itu sendiri sebagai mana yang tercantum dalam sistem olahraga nasional menyatakan bahwa "untuk menumbuhkan budaya olahraga guna meningkatkan kualitas manusia Indonesia sehigga memiliki tingkat kesehatan dan kebugaran yang cukup, serta mempunyai mental yang tangguh“. Daya tahan merupakan kemampuan organisme tubuh untuk melakukan kerja atau aktivitas selama mungkin baik secara statis maupun dinamis tanpa menurunnya kualitas 
kerja. Dengan latihan daya tahan kapasitas paru akan bertambah besar serta menigkatkan kemampuan untuk menampung oksigen yang sangat di perlukan untuk melakukan aktivitas. Tubuh memerlukan energi dalam jumlah besar, tuntutan energi dalam jumlah besar yang dipengaruhi oleh tersedianya oksigen dalam paru, semakin tinggi pulalah tingkat kesagaran jasmani sehingga tingkat daya tahan seseorang semakin tingi pula. Pada cabang olahraga yang menuntut daya tahan yang tinggi diantaranya adalah cabang sepakbola, maka pemasukan oksigen oleh paru secara maksimal memegang peranan di dalam mencapai prestasi yang diharapkan. Sebab bila kemampuan tubuh rendah dalam mengkonsumsi oksigen secara maksimal sulit untuk mendapatkan tubuh yang kuat dan tahan beraktivitas dalam waktu yang lama (Yunus, 2000)

Adapun pentingnya VO2 Max bagi seorang atlet mencapai prestasi didukung dengan kerja keras sehingga kemampuan VO2 Max atlet dapat meningkat. VO2 Max dapat juga disebut sebagai maximal aerobik power atau kapasitas maksimal aerobik, kapasitas maksimal aerobik yang tinggi sangat diperlukan untuk menunjang kemampuan tubuh. Berdasarkan pengamatan peneliti di MAN Simpang Empat Kabupaten Pasaman Barat ditemukan bahwa pemain Sepak bolanya tidak bisa menjalani laga 90 menit dengan maksimal kurang memuaskan hal ini dapat dilihat dari pertandingan antar sekolah sekabupaten pasaman barat yang diadakan setahun sekali, dan prestasinya kurang membanggakan, hal ini disebabkan diantaranya karena kurang bagusnya stamina, kondisi fisik dan kurangnya pengetahuan pemain tentang akan penting kondisi fisik yang baik dan prima, seperti diantaranya adalah daya tahan umum dan daya tahan khusus. Oleh sebab itu perlu dilakukan penelitian untuk melihat sejauh manakah pengaruh metode latihan interval intensif dan metode latihan interval ekstensif terhadap pengembangan VO2 Max Tim sepakbola MAN Simpang Empat Kabupaten Pasaman Barat.

\section{KAJIAN TEORI \\ Metode Interval Intensif}

Menurut Harsono (1993) latihan interval intensif adalah "latihan untuk meningkatkan kecepatan, power, otomatis gerak teknik dan lain-lain". Perlu diingat volume beban latihan banding terbalik dengan intensitas beban latihan. Memperberat beban latihan dapat ditempuh dengan jalan hanya memperbesar volume, meningkatkan intensitas, memperpendek waktu recovery, menambah frekuensi dan tempo tinggi. Dapat pula memperberat beban latihan, meningkatkan secara serempak semua ciri-ciri beban latihan atau sebagian-sebagian".

Jadi latihan interval intensif yaitu salah satu bentuk latihan untuk meningkatkan kecepatan yang dilakukan dengan berat tubuh sendiri. Metoda latihan interval intensif dilakukan dengan jumlah beban yang relatif singkat. Dengan intensitas berkisar antara 10\%-90\%, tinggi berdasarkan lamanya pembebanan antara 30-60 detik, dengan istirahat tidak penuh. Metode interval intensif ini akan mampu meningkatkan saraf-saraf motorik yang komplek. Istirahat yang tidak penuh ini dapat dilakukan dengan istirahat pasif yaitu istirahat tanpa melakukan aktifitas (tidur, berdiri, duduk) dan dalam bentuk istrahat aktif yaitu istirahat dengan melakukan aktifitas yang ringan (lari kecil, jalan). 


\section{Metode Interval ekstensif}

Menurut Suharno (1996) latihan interval ekstensif adalah bentuk latihan yang di gunakan untuk meningkatkan daya tahan aerobic (endurance). Melatih teknik-teknik pada permulaan dan melatih taktik. Latihan interval Ektensif dimaksudkan beban latihan yang diberikan kepada atlet memiliki ciri-ciri antara lain sebagai berikut:"a) Volume latihan besar; b) Intensitas beban latihan rendah atau sedang; c) Waktu recovey lama dan; d) frekuensi dan irama gerak sedikit dan lambat (Harsono dalam Suharno,1993)

Metode latihan interval menurut Roethig dan Grossing dalam Yunus (2001) "pelaksanaannya ditandai dengan intensitas menengah, volume beban bebas berdasarkan banyak pengulangan serta diiringi dengan istrahat tidak penuh atau sempurna". Istirahat yang tidak penuh adalah latihan harus kembali dimulai apabila denyut jantung sudah mendekati kearah 120-140 kali permenit. Istirahat tidak penuh ini dapat dilakukan dengan istirahat pasif (tidur, berdiri,duduk) dan dalam istirahat aktif (lari kecil, jalan).

Pada metode latihan interval ekstensif, latihan dilakukan beberapa kali pengulangan dan seri. Tiap kali pengulangan dan seri selalu diikuti dengan adanya waktu interval. Yang harus diperhatikan adalah jangan lari dengan prinsip interval training, yaitu adanya pertukaran antara pembebanan dan pemulihan secara sistematis. Dalam metode interval ekstensif lama pembebanan juga sangat menentukan dan ini tergantung apa yang ingin dicapai dalam suatu latihan. Pyke dalam Yunus (2001), membagi lama pembebanan dengan dua bentuk yaitu lambat tetapi dengan jarak yang lebih jauh, kedua cepat akan tetapi dengan jarak yang lebih dekat.

\section{Kaitan Metode Latihan Interval intensif dan Interval ekstensif terhadap VO2 $\operatorname{Max}$.}

Menurut Umar (2007) telah mengungkapkan usaha-usaha yang dapat meningkatan $\mathrm{VO} 2$ Max adalah sebagai berikut:

1. Melakukan latihan yang intensif sesuai dengan program yang telah ditetapkan

2. Meningkatkan kadar hemoglobin, karena hemoglobin ini yang akan membawa oksigen dari paru-paru ke sel jantung tubuh termasuk sel otot rangka

3. Menurunkan denyut nadi istirahat, karena semakin rendah denyut nadi istirahat makanya semakin baiknya kondisi fisik seseorang

4. Menurunkan kadar lemak tubuh, terutama kelebihan lemak menyebabkan obesitas dan kegemukan

Menurut R.Boyke dalam Oktoriko (2006) menjelaskan bahwa metode latihan interval intensif dan interval ekstensif untuk meningkatkan VO2 Max sangat erat kaitannya dan saling mendukung satu sama lain, namun dengan demikian dari metode latihan tersebut memiliki kelebihan dan kekurangan masing - masing. Menurut R.Boyke dalam Oktoriko (2006) menjelaskan bahwa ciri-ciri latihan metode interval intensif adalah sebagai berikut ; 
1. Intensitas latihan. Intensitas untuk latihan antara $80 \%-90 \%$, untuk latihan dengan beban intensitasnya $60 \%$ - 90\% dari kemampuan maksimal.

2. Volume Latihan. Vulome latihan tergantung dari tingkat intensitas latihan yang dilakukan. Karena metode ini intensitasnya tinggi maka repetisinya sedikit.

3. Istirahat. Intensitas yang dilakukan dalam latihan ini tinggi, maka istirahatnya harus panjang dan sebagai patokan dapat dilakukan dengan penurunan denyut jantung, bagi pemula penurunan denyut jantung sampai antara 110-120 denyut/menit atau istirahat antara 2-10 menit. Sedangkan untuk atlet yang sudah terlatih 1,5-3 menit.

4. Lama Latihan. Lamanya beban latihan relatif pendek karena intensitasnya tinggi. Contohnya pada lari 100 meter yang ditempuh dalam waktu 14 detik dan untuk lari 400 meter ditempuh dalam waktu 75 detik.

Sedangkan ciri-ciri latihan metode interval ekstensif adalah sebagai berikut

1. Intensitas Latihan. Intensitas untuk latihan antara 60\%-80\%, untuk latihan dengan beban intensitasnya 50\%-80\% dari kemampuan maksimal.

2. Volume Latihan. Bila stimulus intensitas rendah, maka volume diperbesar. Bila melakukan suatu pekerjaan dengan intensitas sedang maka istirahat harus diperbanyak.

3. Istirahat. Istirahat antara repitisi latihan adalah singkat. Penurunan istirahat dapat dilakukan dengan mengukur denyut jantung setelah melakukan latihan. Penurunan denyut jantung sampai antara 125-130 denyut/menit bagi atlet lanjutan. Sedangkan untuk pemula sampai di antara 110-120 denyut/menit dan istirahat dilakukan dengan aktif.

Lama Latihan. Stimulus lamanya latihan yaitu antara 17-80 detik untuk jarak lari 100-400 meter. Contohnya lari jarak 100 meter harus ditempuh dalam waktu 17 detik.

\section{METODE PENELITIAN}

Jenis penelitian ini adalah Eksperimen semu, Penelitian ini dilakukan dengan menggunakan rancangan Randomized Pretest-Postest Group design, dari segi metodologi rancangan ini dapat dipertanggungjawabkan dan memenuhi syarat untuk jenis penelitian Eksperimen semu. Adapun tempat penelitian ini dilakukan dilapangan sepakbola MAN Simpang Empat Kabupaten Pasaman Barat dan waktu penelitian dilakukan pada tanggal 10 oktober sampai 12 desember 2011. Pertemuan atau pelaksanaan latihannya dilakukan latihan sebanyak 18 kali pertemuan dengan frekuensi 3 kali seminggu dan lama waktu perlakuan adalah 120 menit, hal ini sesuai dengan pendapat yang di kemukakan oleh Ali (1991) bahwa latihan baru akan memberikan efek setelah 6 minggu dan di lakukan 3 kali seminggu". 
Menurut Yunus (2007) Populasi yaitu "totalitas semua nilai-nilai yang mungkin dari pada karakteristik tertentu sejumlah objek yang ingin dipelajari sifat-sifatnya". Populasi dalam penelitian ini adalah seluruh pemain sepakbola MAN Simpang Empat Kabupaten Pasaman Barat berjumlah 20 orang yang dipersiapkan untuk menghadapi Liga Pendidikan Indonesia (LPI) dengan tingkat kelompok usianya sedang atau remaja umur 17 tahun. Populasi adalah subjek penelitian (Arikunto1992). Sampel yang digunakan dalam penelitian ini diambil secara total sampling, dimana seluruh populasi yang digunakan dalam penelitian ini dijadikan sampel.

\section{HASIL PENELITIAN}

\section{Terdapat Pengaruh Signifikan Metode Latihan Interval intensif terhadap Peningkatan VO2 Max}

Berdasarkan analisis paired t-test, diperoleh nilai probabilitas $\mathrm{p}=0.011<$ $0.05 \alpha$, menyatakan bahwa rerata pengukuran variabel sangat kuat (signifikan). Artinya terdapat perbedaan secara nyata dari kelompok tes metode latihan interval intensif. Pada tabel paired samples correlations diperoleh harga korelasi kedua kelompok tes sebesar 0.491 dengan signifikansi 0.150 , menyatakan bahwa kedua kelompok tes tidak memiliki hubungan signifikan terhadap peningkatan VO2 Max. Selanjutnya paired sample test, diperoleh mean differences sebesar 3.530. $\mathrm{T}_{\text {hit }}=3.187$ $>\mathrm{t}_{\mathrm{tab}} 2.262$, dengan $d f=9, P=0.011$. Hal ini membuktikan adanya perbedaan secara nyata pada tes awal (pretest) dan tes akhir(Posttest) terhadap VO2 Max metode latihan interval intensif . Dengan demikian hipotesis kerja yang diajukan dapat dibuktikan. Hasil analisis dapat dilihat pada lampiran.

\section{Terdapat Pengaruh Signifikan Metode Latihan Interval ekstensif terhadap Peningkatan VO2 Max}

Berdasarkan analisis paired t-test, diperoleh nilai probabilitas $\mathrm{p}=0.000<$ $0.05 \alpha$, menyatakan bahwa rerata pengukuran variabel sangat kuat (signifikan). Artinya terdapat perbedaan secara nyata dari kelompok tes metode latihan interval ekstensif. Pada tabel paired samples correlations diperoleh harga korelasi kedua kelompok tes sebesar -0.168 dengan signifikansi 0.643 , menyatakan bahwa kedua kelompok tes tidak memiliki hubungan signifikan terhadap peningkatan VO2 Max. Selanjutnya paired sample test, diperoleh mean differences sebesar $6.410 . \mathrm{T}_{\text {hit }}=5.702$ $>\mathrm{t}_{\mathrm{tab}} 2.262$, dengan $d f=9, P=0.000$. Hal ini membuktikan adanya perbedaan secara nyata pada tes awal (pretest) dan tes akhir(Posttest) terhadap VO2 metode latihan interval ekstensif. Dengan demikian hipotesis kerja yang diajukan dapat dibuktikan. Hasil analisis dapat dilihat pada lampiran.

\section{Metode Latihan Interval ekstensif Lebih Baik untuk Peningkatan VO2 Max dibandingkan Metode Latihan Interval intensif}

Berdasarkan analisis paired t-test, diperoleh nilai probabilitas $\mathrm{p}=0.000<$ $0.05 \alpha$, menyatakan bahwa rerata pengukuran variabel sangat kuat (signifikan). Artinya terdapat perbedaan secara nyata dari kelompok tes metode latihan interval ekstensif dan ekstensif. Pada tabel paired samples correlations diperoleh harga korelasi kedua kelompok tes sebesar 0.131 dengan signifikansi 0.718 , menyatakan bahwa kedua kelompok tes tidak memiliki hubungan signifikan terhadap peningkatan 
VO2 Max. Selanjutnya paired sample test, diperoleh mean differences sebesar 8.640. $\mathrm{T}_{\text {hit }}=10.640>\mathrm{t}_{\mathrm{tab}} 2.262$, dengan $d f=9, P=0.000$. Hal ini membuktikan adanya perbedaan secara nyata pada VO2 Max kedua kelompok tes metode latihan ekstensif dan intensif. Dimana metode latihan interval ekstensif lebih baik dari metode latihan intensif. Dengan demikian hipotesis kerja yang diajukan dapat dibuktikan.

\section{PEMBAHASAN}

Berdasarkan hasil pengujian yang dilakukan ternyata hipotesis alternatif yang diajukan diterima, untuk itu dalam pembahasan berikut ini akan dikaji beberapa hal yang menyebabkan diterimanya hipotesis alternatif yang diajukan. Dalam melakukan metode latihan interval intensif dan interval ekstensif sejak awal atlet sepakbola diberikan latihan yang ringan yaitu waktu yang digunakan untuk latihan mulai dari pemanasan, inti, pendinginan, dari 35 menit sampai 60 menit dan gerakan serta intruksi latihan yang dipergunakan dalam latihan ini bervariasi, sehingga membawa atlit sepakbola selalu dalam suasana yang gembira, senang untuk melakukan gerakan latihan tanpa merasakan kekesalan dan kelelahan yang berarti, latihan ini dilakukan 3 kali dalam satu minggu, dalam pertemuan selanjutnya diberikan latihan yang bertambah baik dan bertambah berat dalam segi gerakan latihan maupun waktu yang digunakan mencapai pertemuan terakhir (18 x pertemuan) waktu pertemuan mencapai 120 menit setiap satu kali latihan.

Sementara itu sebelum diberikan perlakuan dan latihan terhadap atlit sepakbola LPI MAN Simpang Empat Kabupaten Pasaman Barat, maka pada pertemuan pertama dilakukan terlebih dahulu tes awal (pretest) yang bertujuan untuk mengukur dan melihat kemampuan atlit tersebut, setelah diberikan perlakuan dan latihan selama 18 kali pertemuan diukur kembali kemampuan VO2 Max para atlit tersebut(Posttest). Dengan adanya pengukuran tersebut, karena atlit serta para jajaran pendamping tim sepakbola LPI SMK MAN Simpang Empat Kabupaten Pasaman Barat ingin mengetahui hasil yang mereka peroleh selama melakukan Metode latihan interval intensif dan interval ekstensif terhadap peningkatan kemampuan VO2 Max.

Bertitik tolak pada hipotesis yang diajukan yaitu hipotesis pertama menyatakan bahwa terdapat pengaruh signifikan model latihan interval intensif terhadap peningkatan VO2 Max pada pemain Sepak Bola MAN Simpang Empat Kabupaten Pasaman Barat. Setelah dilakukan pengolahan data dan analisa data tersebut maka ditemukan hubungan metode latihan interval intensif dapat meningkatkan kemampuan VO2 Max adalah signifikan diperoleh harga korelasi kedua kelompok tes sebesar 0.491 dengan signifikansi 0.150 , menyatakan bahwa kedua kelompok tes tidak memiliki hubungan signifikan terhadap peningkatan VO2 Max. Selanjutnya paired sample test, diperoleh mean differences sebesar 3.530. Thit $=3.187>$ ttab 2.262, dengan $d f=9, \mathrm{P}=0.011$. Hal ini membuktikan adanya perbedaan secara nyata pada VO2 Max kedua kelompok tes latihan interval intensif

Hipotesis kedua menyatalan bahwa terdapat pengaruh signifikan model latihan Interval ekstensif terhadap peningkatan VO2 Max pada Pemain Sepak Bola MAN Simpang Empat Kabupaten Pasaman Barat. Setelah dilakukan pengolahan data dan analisa data tersebut maka ditemukan hubungan metode latihan interval 
intensif dapat meningkatkan kemampuan $\mathrm{VO} 2$ Max adalah signifikan. diperoleh harga korelasi kedua kelompok tes sebesar -0.168 dengan signifikansi 0.643, menyatakan bahwa kedua kelompok tes tidak memiliki hubungan signifikan terhadap peningkatan VO2 Max. Selanjutnya paired sample test, diperoleh mean differences sebesar 6.410. $\mathrm{T}_{\text {hit }}=5.702>\mathrm{t}_{\mathrm{tab}} 2.262$, dengan $d f=9, P=0.000$. Hal ini membuktikan adanya perbedaan secara nyata pada VO2 Max kedua kelompok tes metode latihan ekstensif

Sementara hipotesis ketiga menyatakan bahwa metode latihan interval ekstensif lebih baik untuk peningkatan VO2 Max dibandingkan metode latihan interval intensif pada Pemain Sepak Bola MAN Simpang Empat Kabupaten Pasaman Barat. Setelah dilakukan pengolahan data dan analisa data tersebut maka diperoleh harga korelasi kedua kelompok tes sebesar 0.131 dengan signifikansi 0.718, menyatakan bahwa kedua kelompok tes tidak memiliki hubungan signifikan terhadap peningkatan VO2 Max. Selanjutnya paired sample test, diperoleh mean differences sebesar 8.640. $\mathrm{T}_{\text {hit }}=10.640>\mathrm{t}_{\mathrm{tab}} 2.262$, dengan $d f=9, P=0.000$. Hal ini membuktikan adanya perbedaan secara nyata pada VO2 Max kedua kelompok tes metode latihan ekstensif dan intensif. Dimana metode latihan interval ekstensif lebih baik dari metode latihan intensif.

Berdasarkan uraian di atas dapat dijelaskan bahwa metode latihan interval intensif cukup memberikan sumbangan yang efektif terhadap peningkatan kemampuan VO2 Max, begitu juga dengan metode latihan interval ekstensif cukup memberikan sumbangan yang efektif terhadap peningkatan kemampuan $\mathrm{VO} 2$ Max. Setelah melihat dari perbandingan hasil peningkatan kemampuan VO2 Max dengan memakai metode latihan tersebut, maka Metode Latihan Interval ekstensif Lebih Baik untuk Peningkatan VO2 Max dibandingkan Metode Latihan Interval intensif pada Pemain Sepak Bola MAN Simpang Empat Kabupaten Pasaman Barat. Hal ini juga memberikan gambaran bahwa semakin sering,rutin dan teratur melakukan latihan dengan memakai metode latihan interval intensif dan interval ekstensif maka akan dapat meningkatkan kemampuan VO2 Max. 


\section{SIMPULAN}

Berdasarkan hasil penelitian dan pembahasan, maka simpulan dalam penelitian ini, yakni sebagai berikut :

1. Terdapat pengaruh signifikan metode latihan interval intensif terhadap Peningkatan VO2 Max pada Pemain Sepak Bola MAN Simpang Empat Kabupaten Pasaman Barat. Setelah dilakukan pengolahan data dan analisa data tersebut maka ditemukan hubungan metode latihan interval intensif dapat meningkatkan kemampuan VO2 Max adalah signifikan diperoleh mean differences sebesar 3.530. Thit $=3.187>$ ttab 2.262, dengan $d f=9, \mathrm{P}=0.011$. Hal ini membuktikan adanya perbedaan secara nyata pada VO2 Max kedua kelompok tes latihan interval intensif

2. Terdapat pengaruh signifikan metode latihan interval ekstensif terhadap Peningkatan VO2 Max pada Pemain Sepak Bola MAN Simpang Empat Kabupaten Pasaman Barat. diperoleh mean differences sebesar 6.410. $\mathrm{T}_{\text {hit }}=$ $5.702>\mathrm{t}_{\mathrm{tab}} 2.262$, dengan $d f=9, P=0.000$. Hal ini membuktikan adanya perbedaan secara nyata pada VO2 Max kedua kelompok tes metode latihan ekstensif

3. Metode latihan interval ekstensif lebih baik untuk peningkatan VO2 Max dibandingkan metode latihan interval intensif pada Pemain Sepak Bola MAN Simpang Empat Kabupaten Pasaman Barat. Setelah dilakukan pengolahan data dan analisa data tersebut maka diperoleh harga korelasi kedua kelompok tes sebesar 0.131 dengan signifikansi 0.718, menyatakan bahwa kedua kelompok tes tidak memiliki hubungan signifikan terhadap peningkatan $\mathrm{VO} 2$ Max. Selanjutnya paired sample test, diperoleh mean differences sebesar 8.640. $\mathrm{T}_{\text {hit }}=10.640>\mathrm{t}_{\text {tab }} 2.262$, dengan $d f=9, P=0.000$. Hal ini membuktikan adanya perbedaan secara nyata pada VO2 Max kedua kelompok tes metode latihan ekstensif dan intensif. Dimana metode latihan interval ekstensif lebih baik dari metode latihan intensif. 


\section{DAFTAR PUSTAKA}

Ali. (1991). Ilmu Melatih Olahraga, Bandung : Pustaka Setia Arikunto, S. (1993). Prosedur Penelitian. Jakarta : PT Rineka Cipta

Bompa, T.,O. (2005). Theory and Methodology of Training The Keyto Atletic Performance Second Edition. Kendall/ Hunt Publishing Company.

Harsono. (1996). Latihan Kondisi Fisik: Jakarta: Pustaka Setia

Oktoriko. (2006). Pengaruh Tes Lari Multi Tahap terhadap Peningkatan VO2MAX. Padang : FIK UNP

Suharno. (1993). Penyusunan Program latihan. Jakarta : Komite olahraga Nasional Indonesia, Puasat Pendidikan dan Penataran

Umar. (2007). Kesegaran Jasmani Ditentukan oleh Berbagai Komponen Kondisi Fisik. Padang.

Undang Undang Republik Indonesia Nomor. 3 Tahun 2005. Sistem Keolahragaan Nasional. Yogyakarta: Pustaka. Yustisia.

Yunus. (2001). Pengaruh Metode Latihan Fartlek dan Metodologi latihan interval ekstensif terhadap peningkatan kapasitas Maksimal Aerobik. Skripsi : UNP 